\title{
$13: 27967232-27773790$
}

National Cancer Institute

\section{Source}

National Cancer Institute. 13:27967232-27773790. NCI Thesaurus. Code C42282.

Physical location of FLT1_Gene 